\title{
山形鋼部材の極低サイクル疲労破壊実験 VERY LOW-CYCLE FATIGUE TESTS OF STEEL ANGLES
}

\author{
岩井 哲*，朴錬 洙**，野中泰二郎***，亀田弘行**** \\ Satoshi IWAI, Yeon-Soo PARK, Taijiro NONAKA and Hiroyuki KAMEDA
}

\begin{abstract}
An experimental investigation has been performed on very low-cycle fatigue failure of steel angles under repeated loading. The objective of this study is to extract decisive factors causing cracks and rupture in the course of loading repetitions of the order of a few to twenty cycles. Visible cracks were initiated on the concave side of the bending deformation when it was stretching. Energy dissipation capacity depends heavily on the entire history of loading, failure mode, slenderness ratio and width-to-thickness ratio. Residual strains at the outbreak of a crack were of the order of $25 \sim 40 \%$, irrespective of the test parameters.
\end{abstract}

Keywords : steel structure, repeated loading, low-cycle fatigue, buckling, absorbed energy, residual strain 鉄骨構造, 繰り返し載荷, 低サイクル疲労, 座屈, 吸収エネルギー, 残留ひずみ

\section{1. 研究の目的と位置付け}

構造物が破壊的な地震などによる厳しい繰り返し載荷 を受ける場合，その構造物の要素は部分的に大きな塑性 変形を繰り返し受ける。この時, 繰り返し数は少なくて も塑性化の度合いが非常に大きくなると，構造物は極低 サイクルの繰り返し塑性変形によって破壊する可能性が ある。本研究の主たる目的は，鋼部材が大きな塑性変形 を繰り返し受けることにようて，亀裂発生を伴う損傷を 受けて破断に至る破壞過程を調へ，塑性疲労損傷・破壊 に大きく影響する要因を抽出し, 構造的破壊と各要因と の定量的関係を把握することにある。

本研究は山形鋼を扱うが, 研究のねらいは山形鋼その ものの使用状況を対象にするというよりも，より一般的 な鋼薄内断面材の塑性疲労破壊現象を対象に考えるもの である。ここでは, 部材の全体曲げ座屈や局部座屈の変 形の繰り返しに起因する亀裂発生や最終的な破断とい う, 部材特性にかかわる塑性疲労問題を，これまで多く の成果のある材料特性に基づく疲労破壊規準と関連づけ て評価できるか否かを調べることを目指している。試験 体の山形鋼は，既に実験を行った鋼板要素の座屈後塑性
疲労の成果と対応づけられるような 2 枚の板要素が組み 合わさった比較的単純な断面形状をもつ材として選ん だ。山形断面材を用いることによって，幅厚比が明確に 定義されること, 全体曲げ座屈と局部座屈が連成する挙 動が調べられること, 部材断面が曲げ圧縮・曲げ引張 · 純引張といった基本的な局面を経験する本実験の載荷 で，複雑な破壊挙動解明のための基礎資料を得ることが できると考えられる。

構造物の破壊・損傷の形態は，一般に応力・ひずみな ビの力学的因子, 腐食などの化学的因子と, 使用される 材料の特性との組み合わせによって変化する。構造物で 問題となる破壊としては, 材料中に何らかの要因で潜在 したり，あるいは成長したミクロまたはマクロな欠陥や 亀裂から瞬間的に破溒を引き起こす胞性破壊, 荷重ある いは変位の増加に伴って安定な亀裂が発生・成長し, 最 終的には急速な塑性不安定破壊に至る延性破壊, 繰り返 し荷重に対する疲労破壊, その他に応力腐食割れ,クリー プ破壊などが挙げられる。

材料レベルにおいては, 繰り返し荷重に対する疲労強 度は，よく知られているように $S-N$ 曲線を用いて表さ

\footnotetext{
本論文の一部は, 文献 30$), 31)$ および平成 3,4 年度の日本建築学会大会と土木学会大会, ならびに第 10 回世界地震工学会議（マドリッド，1992）で既 に発表している。

* 京都大学防災研究所 助手・工博

** 京都大学大学院工学研究科 大学院生.工修

*** 京都大学防災研究所 教授 P Ph. D. . 工博

**** 京都大学防災研究所 教授・工博

Research Assoc., Disaster Prevention Research Institute, Kyoto Univ., Dr. Eng.

Graduate Student, Graduate School of Engineering, Kyoto Univ., M. Eng.

Prof., Disaster Prevention Research Inștitute, Kyoto Univ., Ph. D., Dr. Eng. Prof., Disaster Prevention Research Institute, Kyoto Univ., Dr. Eng.
} 
れる。これは材料, 熱処理条件などの内的条件のみでは なく, 負荷様式, 切欠き, 寸法, 表面仕上げ状態, 環境 などの外的条件によっても異なるなど，それに影響する 因子は極めて多く複雑な挙動を示す。寿命が $10^{4}$ 回以下 である疲労を，いわゆる低サイクル疲労あるいは塑性疲 労と呼ぶ。この場合の寿命の評価は，ひずみを規準とし て行われるのが普通である”。

鋼構造部材レベルの低サイクル疲労の問題は, 筋かい 材やトラス材のような細長い材が繰り返し軸方向力を受 ける場合，あるいは $\mathrm{H}$ 形鋼のような薄肉断面材のプレー ト部が繰り返し曲げないしは曲げと軸力を受けるような 場合にしばしば生じる。特に部材の繰り返し載荷奏験で は,一旦座屈して局所的に大きな塑性変形を受けた後; さらに引張・王縮の繰り返しによって極少ないサイクル 数で破壊するような現象が見られる。したがって, 強震 時のような,たかだか数十回程度の塑性変形域での繰り 返しによって，たとえ破断に至らずとも，大きな損傷を 受ける可能性のあることに注目することが必要である。 本研究で対象とする繰り返しによる破壊挙動は, 数回か ら十ないし二十回で破断に至る「極低サイクル」疲労現 象であるが，これは疲労破壊的というよりも，変位の増 加に伴って亀裂が発生・成長する延性破壊的な様相を呈 している。

構造部材を扱ったこれまでの研究の成果では, 文献 2)，3）において著者らが言及したように, 主として数 十一数百あるいはそれ以上のサイクル数の繰り返し載荷 による破壊が取り上げられ，ここで考えているような極 低サイクルでの繰り返しによる破壊を対象としたものは まだほとんどない。構造部材の一定変位振幅下の繰り返 し曲げ挙動は履歴ループが定常状態となるか, 劣化する かの 2 種に大きく分けられる41-11!。劣化を示す場合は, 局部変形や不安定現象の発生にかかわっており, 定常状 態となる場合に比べて，より早く疲労破壊に至る場合が ある。軸方向圧縮力が存在する場合は, その少化挙動を さらに早めることになる(2)-17)。これらの実験結果は一 般に, 載荷変位振幅と破壊時の繰り返し数との関係が両 対数グラフ上で負勾配をもつ直線で表されることが多 い。しかし破壊状態の定義は各研究者によってまちまち でまだ統一されていない。

実際の構造物に作用する荷重は，一定振幅であること はまれであり, 通常は平均や振幅が複雑に変化する不規 則的変動荷重である。変動荷重下の疲労強度は, 荷重の 大きさの頻度分布のみでなく, 載荷順序により変化する。 しかし一般には頻度分布のみを考えて, 一定振幅試験結 果に基づいて推定する線形累積損傷則，いわゆるマイ ナー則 ${ }^{18)}$ な゙が広く用いられている。材料レベルでも， この関係は各応カレベルの繰り返し数が比較的少なく, また応力変動範囲も小さく周期的に繰り返し変動が起こ
る場合は成立するが, 変動回数の少ない場合には，高 · 低応力の負荷順序なよ゙荷重パターンの違いにより累積疲 労損傷の程度は異なる1”。構造物に対して，地震時にお ける非定常載荷下での，疲労寿命あるいは看積的な損傷 を評価する理論・解析方法は多く提案されているもの

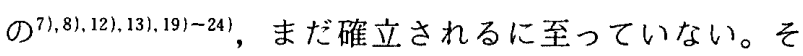
の理由としては，実験的に現象をとらえようとした研究 が主体でまだ疲労破壊の機構そのものが十分にわかって いるわけでないことと, 破壊自体がばらつきの多い現象 であるため厳密に考察することが困難であることが挙げ られる。

著者らは既に局部座屈部分の破壊挙動を調べるため, 鋼部材板要素を対象として，初期に座屈を生じた後の圧 縮・引張繰り返しによる破壊性状を実験的に調へ，板要 素の極低サイクル疲労では，非常に大きな塑性変形が生 じた部位におけるひずみの大きさと，亀裂の発生や破断 とが密接に関係する可能性が認められた 251,26)。本論文で は，全体座屈が局部座屈を伴って生じるような構造部材 としての挙動を夷験的に調べため山形鋼を試験体に選 び，数回からせいぜい二十回程度の極低サイクルの繰り 返し載荷による疲労破壊現象を観察した。ここでは，細 長比, 幅厚比, 載荷パターン, ならびにたわみ変形モー ドの違いが破壊挙動, 繰り返しサイクル数, 履歴吸収工 ネルギー, 局所残留ひずみなどに与える影響に注目して， 実験結果をまとめ，比較し考察を加えた。特に極低サイ クルの疲労破壊条件に関与する亀裂や破断に主要な影響 を及ぼすと考えられる局所ひずみの分布に焦点を当てて 実験を遂行した。

\section{2. 実験計画}

\section{1 試験体}

試験体は合計 20 体で，SS 400 材相当の山形鋼 L-40 $\times 40 \times 3$ と L-40×40×5 を用いて Fig. 1 のように製作 した。試験部長さ $l$ は, $318 \mathrm{~mm}$ (もしくは $300 \mathrm{~mm}$; と もに“L”シリーズと呼ぶ) と $618 \mathrm{~mm}$ (“H”シリーズ と呼ぶ）の 2 種を用いた。試験体に用いた脚幅 $b=40$ $\mathrm{mm}$ の山形鋼の板厚 $t$ は公称值で $3 \mathrm{~mm}$ と $5 \mathrm{~mm}$ の 2 種 で, 公称寸法による幅厚比 $b / t$ は 13.3 と 8 であるが, 実寸法に基づく幅厚比はそれぞれ $15.8 \sim 16.4$ と 8.6 と なっている。ただし， $t=3 \mathrm{~mm}$ の山形鋼はロットの異 なる 2 種が使われ， $t=5 \mathrm{~mm}$ のものを含めて Table 1 ならびに Table 2 に，II，IIIで示す 3 つの材料特性が あるが，大きな差はない。

Table 2 で, 試験体には名前と番号 (No.) を併記した。 試験体名は実験変数を表すものとしており，その付け方 をTable 2 の欄外に示した。なお，試験体名 4 文字の後 に“a”あるいは“b”と付けたものは，全く同じ載荷 条件による実験を行った場合で，2体ずつ 2 組ある。試 

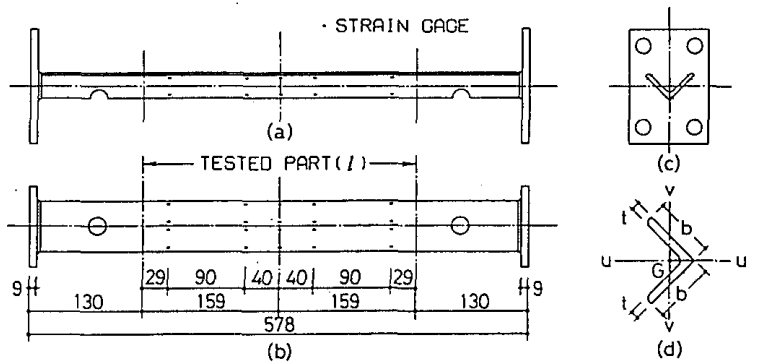

(d)
Table 1 Mechanical properties of materials

\begin{tabular}{|c|c|c|c|c|c|c|}
\hline Type & Angle & $\begin{array}{c}\text { Cross- } \\
\text { sectional } \\
\text { area } \\
A\left(\mathrm{~mm}^{2}\right) \\
\end{array}$ & $\begin{array}{c}\text { Upper } \\
\text { yield } \\
\text { stress } \\
\left(\mathrm{N} / \mathrm{mm}^{2}\right)\end{array}$ & $\begin{array}{c}\text { Lower } \\
\text { yield } \\
\text { stress } \\
\left(\mathrm{N} / \mathrm{mm}^{2}\right) \\
\end{array}$ & $\begin{array}{l}\text { Ultimate } \\
\text { strength } \\
\left(\mathrm{N} / \mathrm{mm}^{2}\right) \\
\end{array}$ & $\begin{array}{c}\text { Elongation } \\
(\%)\end{array}$ \\
\hline$\underset{\text { III }}{\text { I }}$ & $\begin{array}{l}\text { L- } 40 \times 40 \times 3 \\
\text { L- } 40 \times 40 \times 3 \\
\text { L- } 40 \times 40 \times 5\end{array}$ & $\begin{array}{l}216 \\
200 \\
338\end{array}$ & $\begin{array}{l}396 \\
351 \\
356\end{array}$ & $\begin{array}{l}371 \\
336 \\
339\end{array}$ & $\begin{array}{l}465 \\
449 \\
469\end{array}$ & $\begin{array}{l}31.2 \\
29.7 \\
27.1\end{array}$ \\
\hline
\end{tabular}

Fig. 1 Test specimen (length in $\mathrm{mm}$ )

Table 2 Specimen sizes and test parameters

\begin{tabular}{|c|c|c|c|c|c|c|c|c|c|}
\hline $\begin{array}{l}\text { Specim } \\
\text { Name }\end{array}$ & $\begin{array}{l}\text { nen } \\
\text { No. }\end{array}$ & $\begin{array}{c}\text { Material } \\
\text { type }\end{array}$ & $\begin{array}{l}\text { Length } \\
l(\mathrm{~mm})\end{array}$ & $\begin{array}{c}\text { Width } \\
b(\mathrm{~mm})\end{array}$ & $\begin{array}{l}\text { Thickness } \\
t(\mathrm{~mm})\end{array}$ & $\begin{array}{c}\text { Slenderness } \\
\text { ratio } \lambda\end{array}$ & $\begin{array}{l}\text { Width-to- } \\
\text { thickness } \\
\text { ratio } b / t\end{array}$ & $\begin{array}{l}\text { Loading } \\
\text { pattern }\end{array}$ & $\begin{array}{l}\text { Deflection } \\
\text { mode }\end{array}$ \\
\hline L3IP & 13 & I & 318 & 39.6 & 2.80 & 40.7 & 14.1 & I & $\mathbf{P}$ \\
\hline L3IN & 4 & II & 301 & 40.4 & 2.55 & 37.6 & 15.8 & I & $\mathrm{N}$ \\
\hline $\mathrm{L} 3 \mathrm{CP}_{\mathrm{a}}$ & 6 & II & 300 & 40.3 & 2.55 & 37.5 & 15.8 & C & $\mathbf{P}$ \\
\hline $\mathrm{L} 3 \mathrm{CP}_{\mathrm{b}}^{\mathrm{a}}$ & 18 & I & 318 & 39.6 & 2.83 & 40.7 & 14.0 & C & $\mathrm{P}$ \\
\hline L3CN & 5 & II & 301 & 40.5 & 2.47 & 37.6 & 16.4 & C & N \\
\hline L3GP & 16 & I & 318 & 39.5 & 2.80 & 40.7 & 14.1 & G & $\mathbf{P}$ \\
\hline L3SP & 17 & I & 318 & 39.5 & 2.82 & 40.7 & 14.0 & S & $\mathbf{P}$ \\
\hline L3GN & 14 & I & 318 & 39.5 & 2.78 & 40.7 & 14.2 & G & N \\
\hline L3SN & 15 & I & 318 & 39.6 & 2.79 & 40.7 & 14.2 & $\mathrm{~S}$ & $\mathrm{~N}$ \\
\hline LSIP & 9 & III & 318 & 39.2 & 4.56 & 41.9 & 8.6 & I & $\mathbf{P}$ \\
\hline LSIN & 7 & III & 300 & 39.2 & 4.58 & 39.5 & 8.6 & I & $\mathrm{N}$ \\
\hline $\mathrm{L} \mathrm{CP}_{\mathrm{a}}$ & 8 & III & 317 & 39.3 & 4.55 & 41.8 & 8.6 & C & $\mathbf{P}$ \\
\hline $\mathrm{L}^{2} \mathrm{CP}_{\mathrm{b}}$ & 10 & III & 317 & 39.2 & 4.55 & 41.8 & 8.6 & C & $\mathbf{P}$ \\
\hline L5CN & 11 & III & 318 & 39.2 & 4.55 & 41.9 & 8.6 & C & $\mathrm{N}$ \\
\hline H3IP & 19 & II & 618 & 40.3 & 2.49 & 77.2 & 16.2 & I & $\mathbf{P}$ \\
\hline H3IN & 21 & II & 618 & 40.2 & 2.50 & 77.2 & 16.1 & I & N \\
\hline $\mathrm{H} 3 \mathrm{CP}$ & 20 & II & 618 & 40.3 & 2.50 & 77.2 & 16.1 & C & P \\
\hline $\mathrm{H} 3 \mathrm{CN}$ & 22 & II & 618 & 40.4 & 2.50 & 77.2 & 16.2 & C & $\mathrm{N}$ \\
\hline H3GP & 23 & II & 618 & 40.2 & 2.51 & 77.2 & 16.0 & G & $\mathrm{P}$ \\
\hline H3SP & 24 & II & 618 & 40.4 & 2.49 & 77.2 & 16.2 & $\bar{S}$ & $\mathrm{P}$ \\
\hline
\end{tabular}

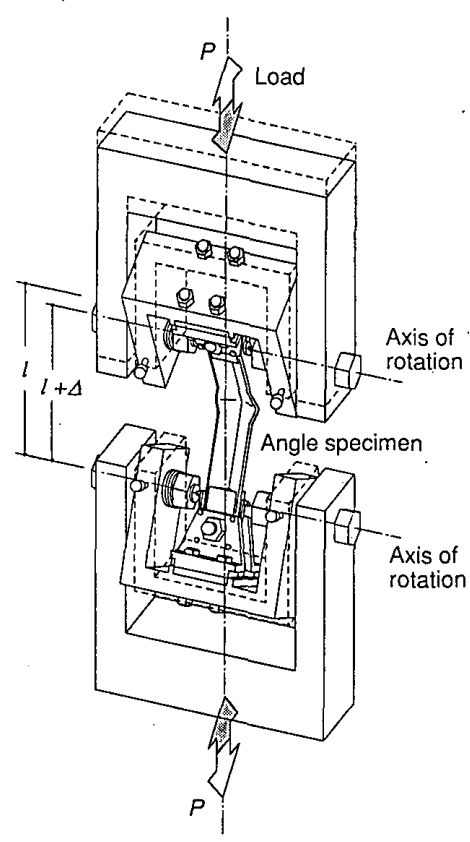

Fig. 2 Loading system
Specimen Identification

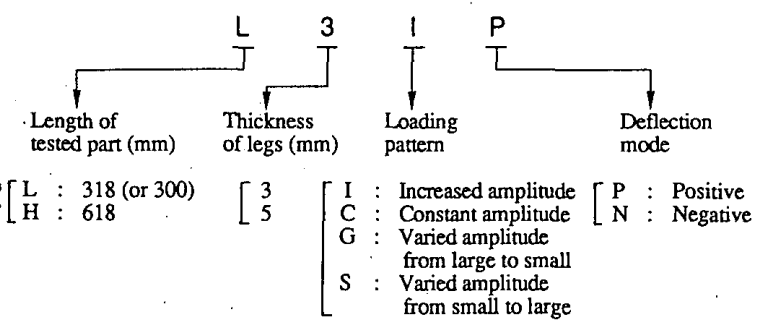

験体番号は実験を遂行した順を示している。No. 8 以降 の番号の試験体には, 両端部に $9 \mathrm{~mm}$ 厚鋼板を山形鎙に 垂直に溶接接合したが，それ以前のものは端部鋼板をも たない。これは後者で, 特に板厚 $5 \mathrm{~mm}$ の山形鋼試験体 の場合, 試験体端部での高力ボル卜摩擦接合耐力に不足 があり，載荷初期に滑りを生じることがあったためであ る。No.18 までの試験体は, 端部鋼板の有るものが $l=$ $318 \mathrm{~mm}$, 無いものが $l=300 \mathrm{~mm}$ となっている。なお最 小断面 2 次半径 $i$ は, L- $40 \times 40 \times 3$ が $7.81 \mathrm{~mm}$ (Type I) と $8.01 \mathrm{~mm}$ (Type II ; 公称值で $7.90 \mathrm{~mm}$ ), L-40 $\times 40 \times 5$ が $7.59 \mathrm{~mm}$ (Type III ; 公称値で $7.74 \mathrm{~mm}$ ) で ある。“L”シリーズと“H”シリーズに対応する細長 比 $\lambda=l / i$ はそれぞれ 37.5 - 42 および 77 である。

\section{2 実験変数}

本研究では, 実験変数として試験体の(1)細長比 $\lambda=$ $l / i(l$ : 有効部材長, $i$ : 最小断面 2 次半径) と(2)幅厚 比 $b / t$ ( $b$ : 脚幅, $t:$ 板厚), (3)繰り返し載荷パターン, (4)たわみ変形モードをとった。試験体の実測寸法と, 各 試験体に与えた実験変数の設定条件を Table 2 に示す。

Fig. 2 に示す装置を用いて試験体の軸方向相対変位 $\Delta$ を制御する静的な定速度繰り返し載荷を行った。この装 置によって試験体を高力ボルトと普通ボルトで固定し $\tau$, Fig. 1(d) の断面重心 $\mathrm{G}$ を通る主軸 $u, v$ の内， $u$ 軸回りならびに材軸回りの回転を拘束し， $v$ 軸回りの回 転のみ自由にした両端ピンの条件で支持し，断面重心位 置に材軸方向の繰り返し加力を行った。変位 $\Delta$ はすべ ての試験体について縮む変形域でのみ作用させた。これ は引張破断によらない破壊性状の把握を目指し，圧縮変 位側での座屈後の繰り返し載荷に焦点を絞ったこと，な らびに試験体の端部に高力ボルト用の有孔断面を設けた ことによって母材を引張降伏させられるまで載荷できな かったことの 2 つの理由による。荷重 $P$ ならびに $\Delta$ の 符号は引張を与えるものを正とした。載荷パターンは Fig. 3 の 4 通りを用いた。(a) の段階型漸増変位振幅繰 り返し載荷（Ｉ型）と（b）の定変位振幅繰り返し載荷 （C型）に加えて，(c) と（d）の 2 段階定変位振幅繰 り返し載荷（GS 型）は（b）の一定变位振幅載荷を基 本パターンとして, 途中の 6 サイクルを半分の小変位振 


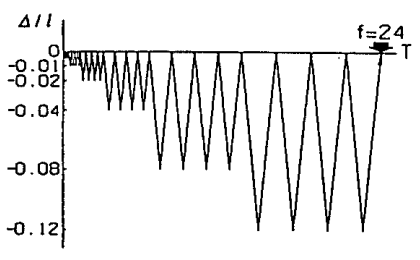

(a) I type loading

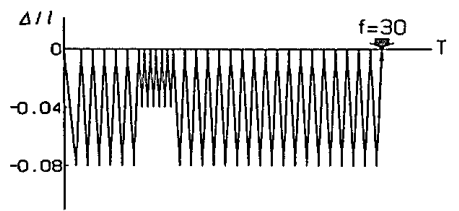

(c) G type loading

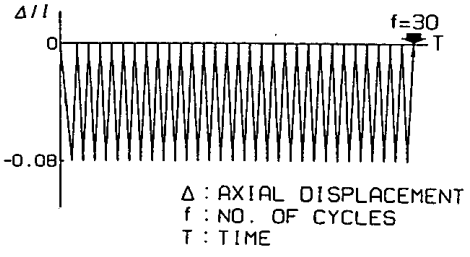

(b) C type loading

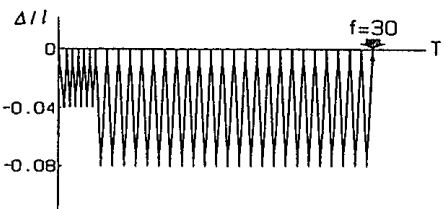

(d) S type loading

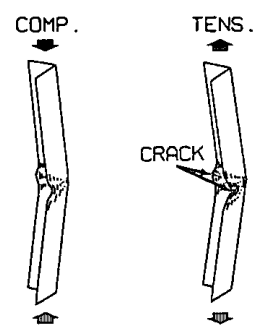

(a) Positive deflection [P] mode
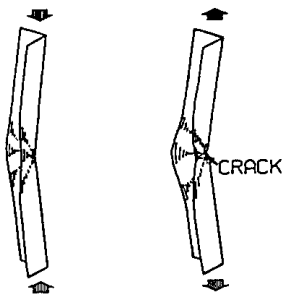

Fig. 3 Loading patterns

Fig. 4 Deflection modes and cracking patterns

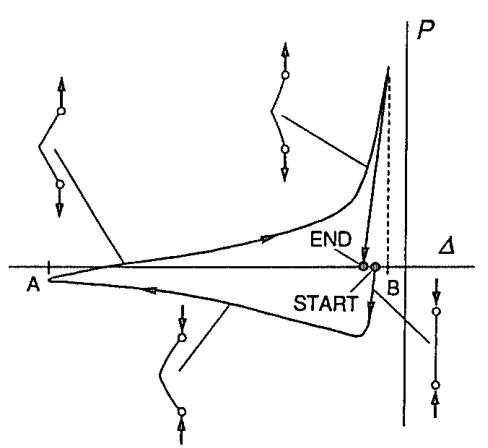

Fig. 6 Definition of one loading cycle

幅で繰り返したものである。計画した総サイクル数は, 漸增変位振幅 [I] 型 24 サイクル, 定変位振幅 [C, $\mathrm{G}, \mathrm{S}]$ 型 30 サイクルである。I 型載荷では, 各振幅で 4 サイクルずつの繰り返しを行った。G型載荷は第 7 サ イクル目から， S 型載荷は第 1 サイクル目から各 6 サイ クルの小変位振幅載荷を与えたもので, 双方共第 13 サ イクル目以降では同じ変位履歴を受けたことになり，そ の挙動の差異を調べることを目的の 1 つとした。

山形鎆が中心王縮載荷によって座屈変形する時，たわ みの発生の向きはFig. 4 に示すように 2 通り現れ得る。 したがって結果的にこのたわみの発生の向きが，比較さ れるべき重要な実験変数となった。ここではFig.4(a) を正たわみモード（P型），Fig.4(b) を負たわみモー ド（N型）と定義する。載荷は可能な限り中心圧縮とし たが，座屈後のたわみモードを計画どおりに制御する必 要性から, 載荷実験の多くは, 予備載荷でほぼ中心王縮 状態とみられるひずみ分布を確認した重心位置から， $0.3 \mathrm{~mm} \sim 0.7 \mathrm{~mm}$ 程度の微小な偏心を与えた。故意に偏 心を与えないで, 座屈時のたわみが正負どちらの向きに 生じても構わないものとして実際に中心圧縮状態で載荷 した試験体は, L 3 IP (No.13), L 3 IN (No.4), L 3 CN (No.5), L 5 IN (No.7) の 4 体である。今回の実
験の目的は座屈変形以後の繰り返しによる破壊挙動の調 査にあり,座屈挙動そのものは特に重要視していないが, 両端ピン支持の実験装置の機能を検証する一つの手がか りとして座屈耐力をみることはできる。

\section{3 載荷方法}

京都大学防災研究所設置の油圧式サーボアクチュエー 夕を用いた載荷実験システムにより加力を行った。載荷 装置を Fig. 5 に示す。載荷装置は基本的に文献 25),26) で用いたものと同じであるが，若干変更を加えた。すな わち, 試験体の上下材端位置でねじれ回転止めを設けた こと, 試験体上下に用いた回転式保持具 (Fig. 2参照) 自体の重量不均衡を解消するためのカウンター・バラン スを取り付けたこと，そして実験時のモニタ一用と計測 用のデータの同時出力のための配線を追加したことなよ゙ である。

ここで用いる1サイクルの数え方は次のように決め た。Fig. 6 に示すように, 軸方向変位 $\Delta$ を气ること によって, 圧縮軸力が生じ, その後与えられた設定変位 Aで折り返すと引張軸力が生じる。さらに変位を戻して, 別の設定変位 Bで折り返し新たに縮みを加える時, 荷重 $P$ が0になる。初めの王縮過程における $P=0$ から, 次 の圧縮過程における $P=0$ までを 1 サイクルと定義す 
る。これは,Fig. 3 の変位制御による $\Delta=0$ から次の $\Delta$ =0の点までの1 サイクルとは一致しないが, 3.4 節に おける履歴吸収エネルギーの算出には，本定義による方 が明確に対応し得るからである。

\section{4 計测方法}

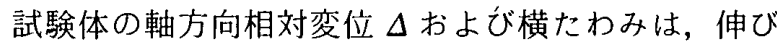
縮みが少なく計測の再現性があるグラスファイバー製の 糸を介して摺動抵抗型変位計で計测し（Fig.5)， $\Delta$ を アクチュエータのフィードバック制御に用い就。

載荷前に対する龟裂発生後の試験体表面の局部残留ひ ずみを測定するため，桑村・前田が用いた局部ひずみの 测定方法 ${ }^{27)}$ を参考にした。桑村らは標点にVickers 圧痕 (点痕) を打ち，荷重を $98 \mathrm{~N}(10 \mathrm{kgf})$ としているが, 本実験に用いたような表面処理を施していない山形鋼の 場合にはそれと同じ方法では標点を認識するのに難が あったため変更した。本実験では, Vickers 硬度試験装 置を用いて，山形鋼断面の脚縁部ならびに稜角部におい て端から $2 \mathrm{~mm}$ 入った位置 (Fig. 10 参照) に, 試験体 材軸方向に $2 \mathrm{~mm}$ のピッチで中央試験区間 $80 \mathrm{~mm}$ にわ たって Knoop 圧痕（線条痕）を標点として打った。打 痕用荷重は $196 \mathrm{~N}(20 \mathrm{kgf})$ ，荷重の保持時間は 5 秒間亡 した。載荷実験終了後，スケール付きルーペなよ゙を利用 して $1 / 10 \mathrm{~mm}$ 精度で伸び量を読みとった。これにより $5 \%$ 単位のひずみ計測が可能となる。また検長 $2 \mathrm{~mm}$ の ひずみゲージをFig.1(a)，(b) に示す位置に貼付し， 降伏棚域までの弾塑性挙動を計测した。

\section{3. 実験結果と考察}

3.1 座屈強度亡変形, 亀裂の発生

実験初期の压縮載荷によって試験体は全体座屈を起こ し，同時に正たわみモードでは，部材中央付近で局部座 屈を生じた。全試験体について，座屈強度の実験值をプ
ロットし座屈曲線と比較したものがFig. 7 である。図 の縦座標は座屈荷重 $P_{c r}$ を降伏軸力 $\sigma_{y} A$ で無次元化し た。横座標は細長比 $\lambda$ に比例し，オイラー座屈強度が 降伏軸力に対応する時の值が 1 となるように定めた。こ こで， $\sigma_{y}$ は鋼材の下位降伏点志力， $A$. は断面積で Table 1 に示した各值をとっている。非弾性座屈曲線と して, Engesser-Shanley の接線係数理論による座屈応 力を示した。ここで，鋼材の比例限度 $\sigma_{\rho}$ を

$$
\sigma_{p}=0.8 \sigma_{y} \cdots
$$

と仮定し，比例限度以上の応力ーひずみ曲線の座屈応力 $\sigma_{c r}$ における接線弾性係数 $E_{t}$ を

$$
E_{t}=E_{s}\left\{1-\left(\sigma_{c r}-\sigma_{p}\right)^{2} /\left(\sigma_{y}-\sigma_{p}\right)^{2}\right\} \cdots
$$

とおいて求めた。 $E_{s}$ は鋼材のヤング係数で $E_{s}=206$ $\mathrm{kN} / \mathrm{mm}^{2}$ とした。

実験結果の一覧を Table 3 に示す。ここに示した $P_{c r}$ は座屈荷重， $f_{c a v}$ は正たわみモードの局部座屈あるいは 負たわみモードの全体坐屈による曲げ変形の凹部側にお いて肉眼で初亀裂が確認できた時のサイクル数， $f_{\text {vex }}$ は 同じく曲げ変形の凸部側で初亀裂を確認した時のサイク ル数， $f_{p e n}$ はそれらの両亀裂発生後に板厚方向に刍裂が 貫通した時のサイクル数， $f_{\text {rup }}$ は破断サイクル数， $E$ は実験終了段階における履歴吸収エネルギーの累積量, $E_{0}$ は試験部全長にわたって蓄え得る最大弾性ひずみ工 ネルギーで

$$
E_{0}=\sigma_{y}^{2} \cdot A \cdot l /\left(2 \cdot E_{s}\right)
$$

で与えられる。 $\varepsilon_{\text {tens }}, \varepsilon_{\text {comp }}$ は亀裂発生部における引張側, 生縮側それぞれの局所ひずみで, 絶対值が最大のもので ある。

荷重はデータ・ロガーを用いて·ディジタルの数值で記 録されたが，奏験では座屈現象は瞬時に起こり，その最 大圧縮荷重をデータ・ロガーで記録できないこともあ る。実験時にはモニターとして X-Yレコーダーによる

Table $3^{\circ}$ Test results

\begin{tabular}{|c|c|c|c|c|c|c|c|c|}
\hline \multirow[b]{2}{*}{$\begin{array}{l}\text { Specimen } \\
\text { name }\end{array}$} & \multirow{2}{*}{$\begin{array}{l}\text { Buckling } \\
\text { load } \\
P_{c r}(\mathrm{kN})\end{array}$} & \multicolumn{4}{|c|}{ Number of load cycles } & \multirow{2}{*}{$\begin{array}{c}\text { Dimension- } \\
\text { less energy } \\
E / E_{o}\end{array}$} & \multicolumn{2}{|c|}{$\begin{array}{l}\text { Strain at cracked portion } \\
\text { Tens. Comp. }\end{array}$} \\
\hline & & $\begin{array}{l}\text { Crack } \\
f_{\text {cav }}\end{array}$ & $\begin{array}{l}\text { Crack } \\
f_{\text {vex }}\end{array}$ & $\begin{array}{l}\text { Crack } \\
f_{\text {pen }}\end{array}$ & $\begin{array}{c}\text { Rupture } \\
f_{\text {rup }}\end{array}$ & & $\begin{array}{c}\text { Tens. } \\
\varepsilon_{\text {tens }}(\%)\end{array}$ & $\begin{array}{c}\text { Comp. } \\
\varepsilon_{\text {comp }}(\%)\end{array}$ \\
\hline L3IP & 71.4 & 17 & 18 & 18 & -- & 131 & -- & -- \\
\hline L3IN & 58.9 & 20 & 21 & 21 & -- & 235 & - & -- \\
\hline $\mathrm{L} 3 \mathrm{CP}_{\mathrm{a}}$ & 64.2 & 9 & 10 & 10 & -- & 133 & 27.5 & -29 \\
\hline $\mathrm{L} 3 \mathrm{CP}_{\mathrm{b}}$ & 66.8 & 5 & 8 & 8 & 23 & 115 & 30 & -32.5 \\
\hline L3CN & 69.0 & 7 & 8 & 8 & -. & 220 & .. & -41 \\
\hline L3GP & 66.0 & 5 & 9 & 10 & 25 & 112 & 27.5 & -35 \\
\hline L3SP & 69.7 & 8 & 12 & 12 & 27 & 122 & 30 & -32.5 \\
\hline L3GN & 72.8 & 6 & -- & 7 & -- & 170 & -- & -30 \\
\hline L3SN & 76.3 & 10 & -- & 11 & -- & 221 & -- & -35 \\
\hline L5IP & 105.2 & 21 & 23 & 23 & -- & 236 & 35 & -35 \\
\hline L5IN & 120.7 & 22 & - & 22 & -- & 410 & - & -30 \\
\hline $\mathrm{L}^{5 \mathrm{CP}_{\mathrm{a}}}$ & 96.7 & 9 & 12 & 12 & 19 & 211 & 32.5 & -35 \\
\hline $\mathrm{L}^{5 \mathrm{CP}_{\mathrm{b}}^{\mathrm{a}}}$ & 109.2 & 9 & 12 & 12 & 19 & 214 & 30 & -32.5 \\
\hline L5CN & 107.5 & 9 & 13 & 13 & 21 & 378 & 35 & -35 \\
\hline H3IP & 68.4 & 18 & 21 & 21 & -- & 78 & 35 & -35 \\
\hline H3IN & 59.9 & 18 & - & 22 & -- & 117 & $\ldots$ & -35 \\
\hline $\mathrm{H} 3 \mathrm{CP}$ & 49.1 & $\begin{array}{l}100 \\
5\end{array}$ & 8 & 9 & 17 & 66 & 32.5 & -35 \\
\hline $\mathrm{H} 3 \mathrm{CN}$ & 58.3 & 5 & - & 8 & - & 104 & - & -35 \\
\hline H3GP & 48.6 & 6 & 9 & 11 & 22 & 75 & 30 & -35 \\
\hline H3SP & 62.7 & 9 & 12 & 12 & 22 & 83 & 35 & -35 \\
\hline
\end{tabular}

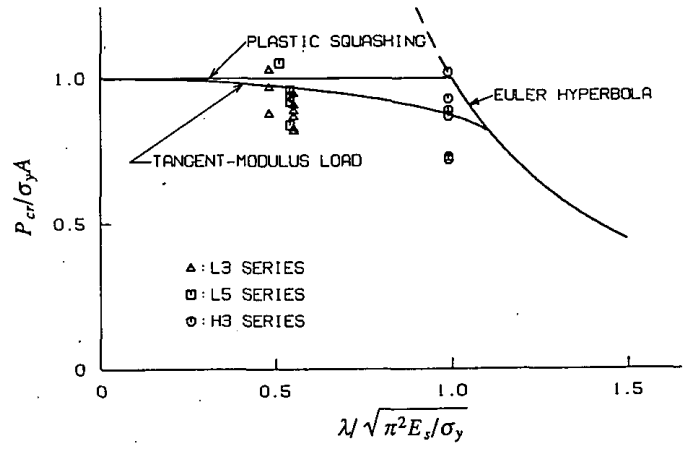

Fig. 7 Column curve and observed strength 
$P-\Delta$ 関係のアナログ記録も同時に行った。図および表 中の $P_{c r}$ は X-Y レコーダーに示された最大荷重值で, 両者の比較では, データ・ロガーの最大荷重値記録の方 が若干低くなる傾向があり, 最大で $4.5 \%$ 程度の差を 生じた注り。本夷験に用いた細長比あたりの座屈実験結 果は座屈荷重の相当ばらつく所であり ${ }^{28)}$, 当結果のばら つきは特に大きいものではない。

Fig.4(a) のような正たわみモードでは，まず山形断 面の両脚縁の局部変形の凹部亡凸部の 2 表面にそれぞれ 初亀裂が発生した後, 載荷とともに亀裂が進展して厚さ 方向内部に進み，断面中央の稜角部まで入り込んだ。 Fig.4(b) のような負たわみモードでは逆に, 両脚付け 根の稜角部に変形が集中し, 全体座屈変形の凹側変形部 が引張力を受けた時に初亀裂が発生した。龟裂の進展は 当然，引張力を受ける部位にみられるが，いずれの載荷 の場合も，局部座屈や全体座屈によって曲げ圧縮変形を 受けた凹側変形部の板要素が, 荷重の反転によって引張 力を受けた時に初鲁裂が観察された。多くの試験体では， 続く荷重再反転後の圧縮載荷で，初亀裂が発生したのと ほぼ同じ材軸方向位置で反対面の曲げ引張側である凸側 に新たに龟裂が発生するという過程が認められた。ここ での亀裂の発生はすべて肉眼での観察によって確認した ものである。実験終了後の試験体の稜角側の刍裂発生部 の写真を Photo. 1 に示す。

全く同じ載荷条件で実験を行った試験体 L $5 \mathrm{CPa}$ と L $5 \mathrm{CPb}$ は最終的に 2 体が同じサイクル数で完全破断 を生じた。これによって疲労実験とはいえ，実験そのも のの再現性がかなりあることが確かめられた。

\section{2 繰り返しサイクル数と破壊挙動}

\section{（1）幅厚比の影響}

載荷予定した最終サイクル数に至る前に破断したのは 9 体であった。正たわみモードの場合は，実験時の制御 困難のため途中で載荷終了した L $3 \mathrm{CPa}$ を除いて, C, G, S 型の定振幅載荷のものすべてが破断に至った。こ の時の破断サイクル数は $f_{\text {rup }}=17$ 27である。負たわ みモードでは L 5 CN 1 体のみが破断し，この時 $f_{\text {rup }}=$ 21 である。両たわみモードとも，亀裂発生時サイクル 数 $f_{\text {cav }}, f_{\text {vex }}$ は幅厚比による差があまりないか，または 幅厚比大の方がサイクル数が少ない傾向にある。しかし 破断サイクル数はむしろ幅厚比の小さい方が少ない注21。

負たわみモードでは，亀裂はすべて材軸に垂直な方向 に現れ (Photo. 1(b)，(d))，亀裂発生位置も全体座屈 で最も箃しい忘力と変形を受ける材中央に出た。正たわ

注 1）平成 4 年度の日本建築学会, 土木学会, ならびに第 10 回世界地震工学会議（マドリッド）の著者らによる研究 概要報告などにおける座屈荷重值の表記はデー夕・ロ ガーによるものであり，T able 3 の值と若干の差がある。

注2）負たわみモードの L 3 CN は 30 回繰り返しても破断し なかったと見なせる。
みモードでは，両縁部の局部座屈と全体座屈とがほぼ同 時に生じるが，局部座屈は必ずしも材中央に生じていな い。重裂は局部座屈発生部で最も変形の大きい位置に生 じ，幅厚比の大きい場合，材軸垂直方向より斜めに現れ る(Photo.1(a))。これは局部座屈が，ねじれ変形を伴っ て両脚で材軸方向にずれた位置で現れたことによる。幅 厚比の大きい場合に材のねじれる傾向が著しい。

\section{（2）細長比の影響}

正たわみモ一ドの場合では，細長比の影響は破断サイ クル数に顕著に現れ，細長比大のものは破断サイクル数 $f_{\text {rup }}$ が各載荷パターンで細長比小のものに比べて $3 \sim 6$ サイクル減少した。しかし亀裂発生時のサイクル数 $f_{\text {cav }}, f_{\text {vex }}$ には細長比による顕著な差はあまりみられな い。また細長比の大きい場合に材のねじれる傾向が著し い。実験によると，ここで用いた細長比程度の同じ断面 形状をもつ山形鋼では局部座屈による変形領域の広がり にあまり差がない。負たわみモ一ドの場合は，龟裂発生 時サイクル数に顕著な影響はみられない。

高橋ら ${ }^{29}$ は, 山形鋼筋違の王縮・引張変位漸増型繰り 返し下での破壊性状を，本実験でいう負たわみに当たる モ一ドで, 種々の幅厚比 (8.3〜12.5) と細長比 $(60,150$, 240）を用いて実験的に調べている。その結果として, (1)幅厚比の大きい方が早いサイクルで破断すること，(2) 細長比の小さい方が早いサイクルで破断すること，が示 された。本実験の，特に正たわみモードの場合の結果は いずれも，これらの結論とは逆の傾向になっている。た だし，細長比は対象とした範囲が異なり，本実験の試験 体の細長比は高橋らの実験の小さい方の值に近い。また (2)については本実験で負たわみモードの破断サイクル数 のデータが得られていない。

\section{（3）載荷経路の影響}

載荷パターンの C, G, S 型繰り返し (Fig. 3 参照) の 3 者の場合を比較して, 載荷径路の影響を調べた。第 6 サイクルまでのC型と $\mathrm{G}$ 型とは同じ載荷条件であり， Table 3 で, 亀裂発生の $f_{\text {cav }}$ における 1 サイクルの値の 差は実験のばらつきと考えられ，両者はほぼ同じ経過を とっている。S 型で $f_{\text {cav }}$ が C, G 型に比べて 3〜4 サイ クル遅れるのは，初めに小振幅の 6 サイクルを経験した ことによる影響とみられる。 $f_{\text {vex }}$ および $f_{\text {pen }}$ は第 8 サ イクル以降となるが，C型とG型でほとんど差がない。 $\mathrm{G}$ 型の 7 サイクル目以降の小振幅繰り返しによって損傷 の進展を緩和する効果が特に現れなかったと言える。 型では $f_{\text {cav }}$ が遅れたのと同じ程度に， $f_{\text {vex }}$ も遅れてい る。破断時の $f_{\text {rup }}$ についてはL 3 シリーズと H 3 シリー ズの差がどの程度, 有意であるか判断するのは難しい。 しかし初めに大きい振幅の載荷を行った方が亀裂発生サ イクル数および破断サイクル数が少なく，やや損傷の大 きい傾向がある。載荷経路の影響については，3.4 節で 


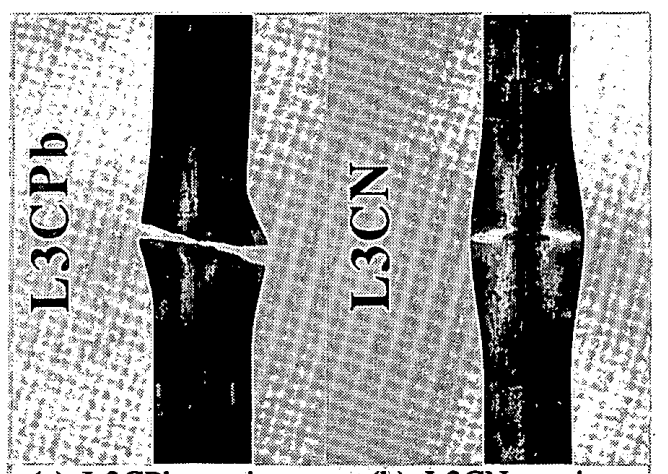

(a) L3CPb specimen

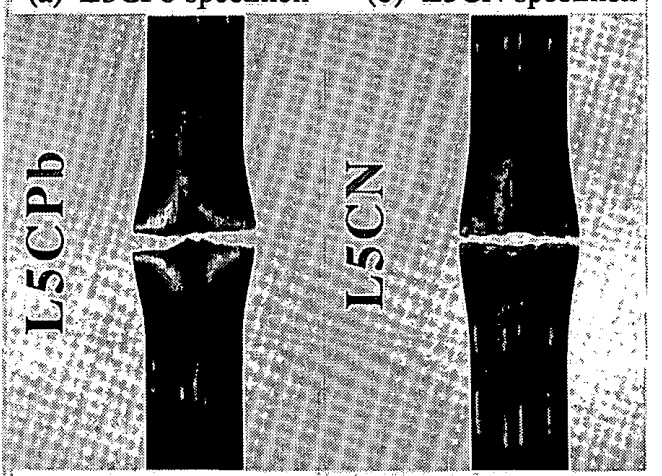

(c) $\mathrm{L} 5 \mathrm{CPb}$ specimen

(d) L5CN specimen

Photo. 1 Cracked and ruptured portions after testing

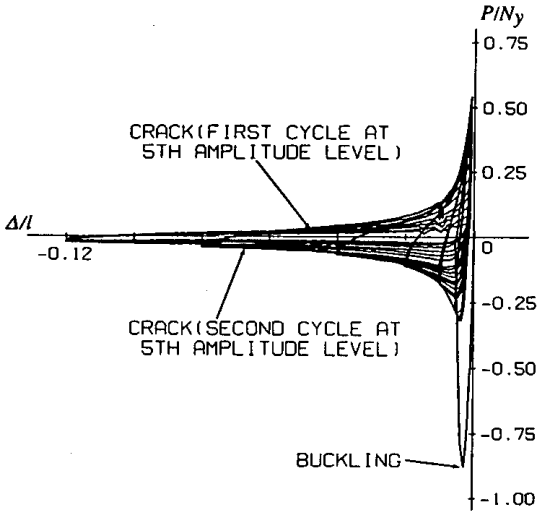

(a) L3IP specimen

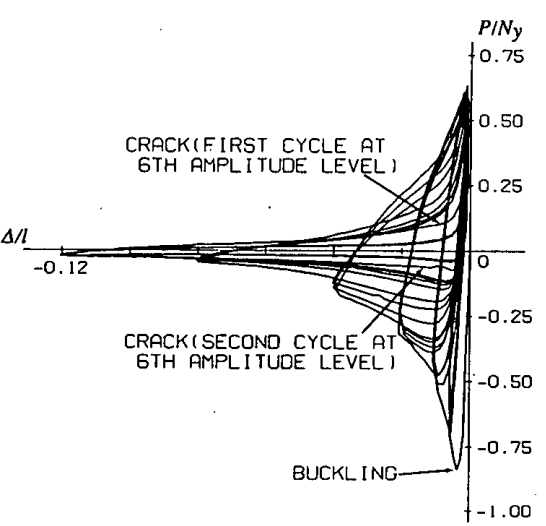

(c) L3IN specimen

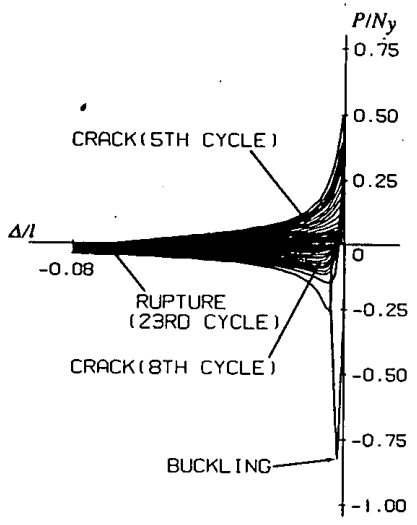

(b) $\mathrm{L} 3 \mathrm{CPb}$ specimen

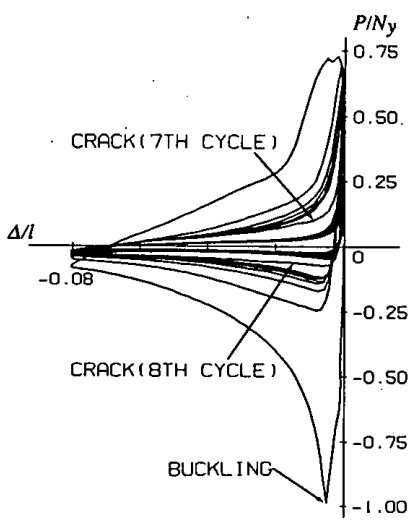

(d) L3CN specimen

Fig. 8 Load-axial displacement relations

エネルギー吸収量の観点から再び若察を加えることにす る。

\section{3 荷重-軸方向変位曲線}

荷重 $P$ と軸方向変位 $\Delta$ の関係の例をFig. 8 に示す。 $N_{y}=\sigma_{y} A$ は断面の降伏軸力である。変位振幅漸増（I） 型載荷では, 試験部長さ $l$ の 8 変位にあたる第 5 振 幅域での繰り返しまでは亀裂は現れず，多くの場合 12 $\%$ 変位にあたる最終の第 6 振幅域での第 1 サイクル目 に亀裂が出始めた。定変位振幅 $(\mathrm{C})$ 型載荷は，この第 5 振幅と同じ $8 \%$ 変位での繰り返しを行っており，第 7 〜9サイクルで最初の亀裂が確認できた。

定変位振幅型載荷を行った武験体では，各サイクルの 履歴曲線が収束し安定する傾向と, 逆に発散し不安定と なる傾向の違いが認められる。各サイクルごとの履歴 ループに劣化による顕著な差が見られるのは, 亀裂が確 認された時点か，もしくはその $2 \sim 3$ サイクル後である。 載荷初期の座屈によって圧縮抵抗力は急激な低下を起こ すが，材料的な損傷はまだ受けていないため；引張力に は抵抗でき，龟裂が発生するまで履歴曲線は徐々に安定 する傾向にある。しかし, 亀裂が発生すると, 引張抵抗 力・圧縮抵抗力共に著しく劣化し破断に至る。

負たわみモードの場合は，正たわみモードの場合と比 べて，膨らみの大きい履歴ループ形状が観察される。ま
た, 幅厚比の小さいL5 シリーズを除いて, 引張強さは 負たわみモードの場合が大きくなっている。負たわみ モードでは, 全体座屈が生じた後, 更に縮められる時, 部材中央では山形断面の再縁部聞距離が広げられる。次 に設定変位で折り返して $\Delta=0$ まで戻る際には，まっす ぐに近い状態に戻り,この時, 元の断面形状に近くなる。 しかし, 特に幅厚比が大きいL 3 シリ一ズの断面, ある いは正たわみモードで局部座屈を伴う座屈変形をした場 合では, $\Delta=0$ の元の変位に戻っても, まっすぐに伸び 切らない状態にある。

また別の顕著な現象の例として, 試験体 $\mathrm{H} 3 \mathrm{CN}$ では, 変位を戻す途中で局部座屈が発生すると同時にねじれ， 履歴ループに明確な折れ曲がりが観察された。しかし， この負たわみモードにおけるねじれ変形は亀裂の発生・ 進展につれて徐々に解消し，載荷終了時には単に材中央 について上下対称な, ねじれのない弱軸曲げ変形しか残 らなかった。

\section{4 履歴吸収エネルギー}

各履歴ループで囲まれた面積から算定した履歴吸収エ ネルギーの累積值 $E$ と繰り返しサイクル数 $f$ との関係 を全試験体について Fig. 9 に示す。図の縦軸は $E$ を最 大弾性ひずみエネルギー $E_{0}$ で無次元化したエネルギー 比である。(a) 図はI 型, (b) 図はC 型, (c)〜 (e) 図 


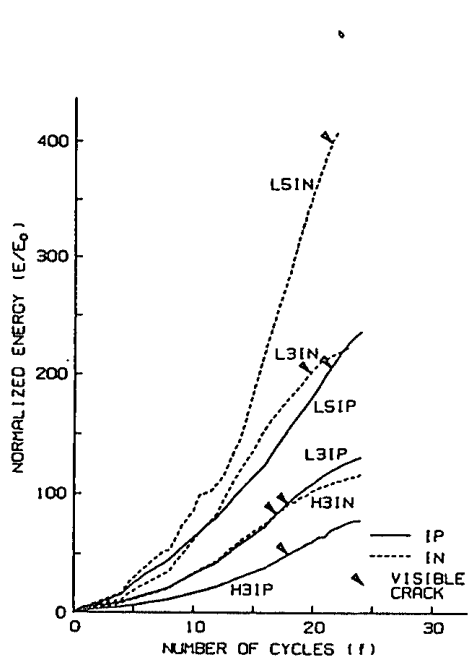

(a) I type loading

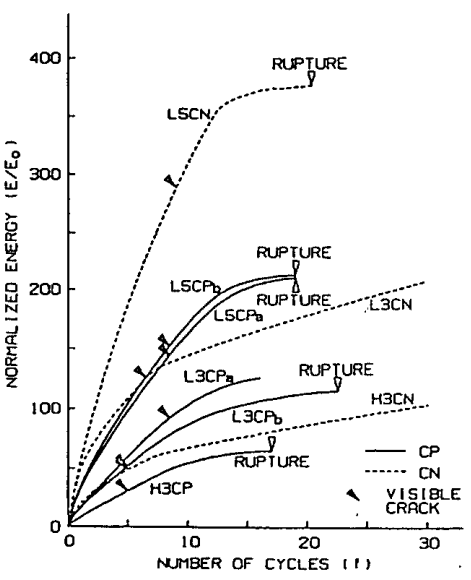

(b) $C$ type loading

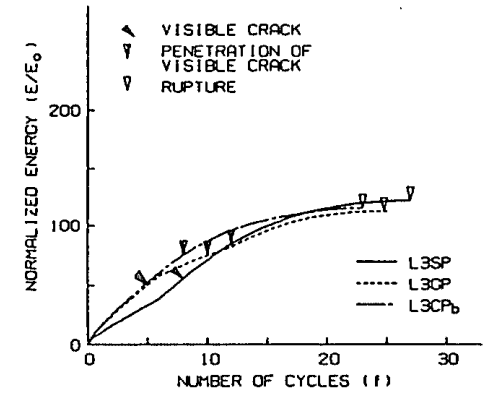

(c) Comparison of S, G and C type loading (L3 series in Positive mode)

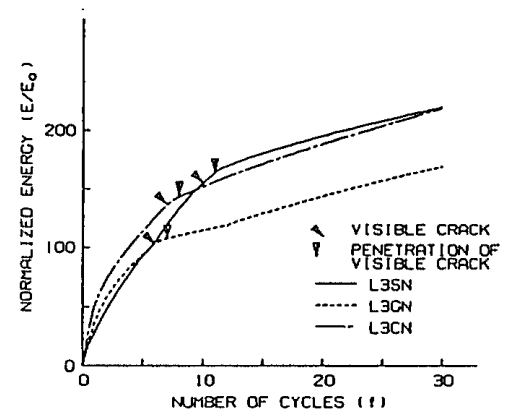

(d) Comparison of S, G and C type loading (L3 series in Negative mode)

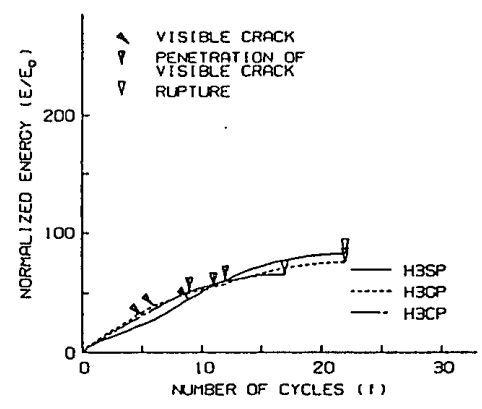

(e) Comparison of S, G and C type loading (H3 series in Positive mode)

Fig. 9 Comparison of energy absorption in the course of increasing number of cycles

はS，G，C 型の 3 者をそれぞれL 3 正たわみモード， L3 負たわみモード, H3 正たわみモードについて比較 したものである。

（1）載荷パターン別の比較

繰り返しに伴う履歴吸収エネルギーの累積過程の各段 階は，I型（Fig.9(a)）とC型 (Fig.9(b)) の別，す なわち載荷パターンによって全く違う性状を示す。また 載荷パターンが同じ場合でも，山形鋼のような 1 軸対称 断面では，横たわみの発生方向の違いによる影響を大き く受ける。負たわみモードの場合の方が正たわみモード の場合より,同じ繰り返し数でもエネルギー比が大きい。 これは亀裂発生が認められた段階（『）までの載荷初期 においても，最終的な破断時（ $\nabla)$ の総エネルギ一量に おいても同様である。正たわみモードと負たわみモード の履歴ループ面積の差はFig. 8 でも明らかに現れてい た。これは負たわみモードでは全体座屈のみ生じたが, 正たわみモードでは全体座屈が局部坐屈を伴って生じ,

抵抗力が下がったことによると考えられる。幅厚比の違 いに関しては，幅厚比小（L5 シリーズ）の場合が幅厚 比大（L3 シリーズ）の場合よりエネルギー比が大となっ ている。幅厚比小の場合にエネルギー比が大となること は，幅厚比が局部座屈に関連していることから理解でき る。また細長比による影響も, 座屈後挙動の履歴ループ の膨らみの違いから, 細長比小の場合にエネルギー比が 大となることがわかる。

これらの諸関係より, 累積エネルギー比がある値を超 えた時に亀裂が発生するという訳ではなく，また最終的 な破断にかかわるエネルギ一比を特定の值で表すことも 困難である。しかし見方を変えれば，累積履歴吸収エネ ルギー特性は極低サイクル疲労破壊と単純な関係にはな いが, 載荷履歴・変形モード・幅厚比・細長比の違いを 顕著に反映するということもできる。これより極低サイ クル疲労による部材の損傷過程を，部材中の局部坐屈発 
生部分などの局所の塑性仕事を算出することで，エネル ギー吸収量によって定量的に評価を行える可能性のある ことが推察される。

\section{（2）同一載荷条件下での比較}

同じ載荷条件で㬰験した 2 組の試験体について，エネ ルギー吸収特性の比較が Fig. 9(b) でなされている。ま ず試験体 L $5 \mathrm{CPa}$ と $5 \mathrm{CPb}$ はほとんど同じエネル ギー吸収挙動をしていることが認められた。亀裂発生時 の繰り返し数や, 亀裂発生後の劣化の過程, 履歴曲線の 形状ならびに破断時のサイクル数など，ほとんど一致し た実験結果が得られたことは, 極低サイクル疲労実験の 再現性のあることを示している。しかし，もう 1 組の $\mathrm{L} 3 \mathrm{CPa}$ と $\mathrm{L} 3 \mathrm{CPb}$ では, エネルギ一特性に若干の差 が現れている。これらのことから, 同じ載荷を行っても 実験結果としてこの程度のばらつきが出ると考えるべき かも知れない。ただし, 前者L5の一対は材料も端部板 溶接の有無も全く同じ条件であるのに対し, 後者L3の 一対は材料のロットが同一でなく，一方が端部プレート 無し, 他方が端部プレート有りのもので, 全く同一の試 験体条件と見なせない点もあり, その影響が皆無とは言 い切れない。

\section{（3）載荷経路の影響}

載荷経路は異なるが，同一の試験体形状に対し，同一 のモードで変形して渑裂を生じ, 破断に至った場合の工 ネルギー吸収能力の比較を, Fig. $9(\mathrm{c}) \sim(\mathrm{e})$ において 行っている。ここでは載荷経路（載荷順序）が異なる 2 体と, それらの基本となる定振幅繰り返し載荷を行った 1 体の，3 体ずつ 3 組の場合についてそれぞれ示してい る。

正たわみモードの場合は, L3 シリーズ (Fig. 9(c)) もH 3 シリーズ (Fig. 9(e)) も良く似た曲線を示してお り, 本実験で行った程度の載荷経路の変化では, 龟裂発 生や破断にかかわるエネルギ一吸収比にあまり差が見ら れない。載荷経路による影響としては, 最初の 6 サイク ルまでは $\mathrm{G}$ 型（破線）とC 型.(鎖線) が一致すること, 7〜12 サイクルで $\mathrm{G}$ 型（破線）が $\mathrm{S}$ 型 (実線) に近寄る ことなど，順序を入れ替えた影響を直接反映しているこ とが認められる。第 13 サイクル目以降のエネルギー吸 収率（曲線の勾配）は，C， G，S 型の順で大きく，損傷 の受け方と対応しているとも考えられる。また，この順 に破断サイクル数も多くなっている。しかし負たわみ モード (Fig.9(d)) の場合の結果は, 正たわみモード の場合ほど合理的な対応は見いだせない。

\section{5 局所残留ひずみ分布}

載荷終了後の局所残留ひずみの大きさと龟裂との関係 は,Fig. 10 に示す断面の脚縁部ならびに稜角部付近で 测った材軸方向のひずみ分布図によって見ることができ る。ここで亀裂発生部のひずみの大きさは，龟裂による
間隙を除いた，材としての正味のひずみを算定したもの で表した。図中，線引きを施した部分は引張ひずみを， 網点を施した部分は圧縮ひずみを表す。正たわみモード (Fig. 10(a)) では，脚縁部の塑性化領域が狭い範囲に 集中して限られており，領域長さは断面の板厚の 4-6 倍程度となっている。稜角部では，ひずみ量はそれより 小さくなるが，塑性化領域長さは長く，板厚の 20 倍程 度まで広がっている。また，塑性化域の中央ではひずみ が付近とは反転し，圧縮を示している。一方，負たわみ モード (Fig.10(b)) では，ひずみ計测を行った $80 \mathrm{~mm}$ の長さ区間の領域全体に塑性化が進んでいる。各試験体 で得られた龟裂発生部の残留ひずみの最大值は, Table 3 に示すように圧縮側・引張側とも絶対値で 25 - 40\% の範囲であった。この值は, 載荷履歴や幅厚比, 細長比, ならびにたわみ発生の向きにかかわらずほぼ同じである ことが注目される。亀裂は引張載荷時に発生するもので あるけれども，特に亀裂発生箇所における圧縮ひずみの 大きさは，試験体が経験した最も大きな曲げ変形に依存 するとも考えられる。したがってひずみの值の範囲を検 証するためには，今回と異なる変形状態による場合を更 に問題設定する必要があるかも知れない。今後の奏験的 課題として，このことも踏まえ，伸び変形を含む載荷パ ターンを変位履歴に入れることを計画中である。

Table 1 に結果を示した単純引張載荷試験に用いた JIS の $13 \mathrm{~B}$ 号材料試験片について, 局部ひずみを同様 の方法で調べた例を，Fig.11に示す。図の横軸は試験 片の材軸方向の座標を表すが，破断を生じた断面位置を 坐標の 0 と置いている。標点間距離 $50 \mathrm{~mm}$ での平均伸 び率が $30 \%$ 程度である場合でも，1.5 mm ピッチある いは $2 \mathrm{~mm}$ ピッチで計測した局部ひずみの最大值は 100 \%にも達している。したがって上記繰り返し載荷時の 亀裂発生に関するひずみ值がこれと比べて相当小さいこ とは,繰り返し載荷による効果によるものと考えられる。

\section{4. 結 論}

山形鋼部材を用いて軸方向相対変位で制御する繰り返 し載荷を行い, 数回から二十回位の極低サイクルの繰り 返しで破壊する現象を実験的に観察し，調查した。本実 験で行った実験変数の範囲で得られた知見を次に要約す る。

1）亀裂の進展は当然, 引張応力を受ける部位にみられ るが,いずれの載荷の場合も, 局部座屈・全体座屈によっ て曲げ圧縮変形を受けた凹側変形部の板要素が, 繰り返 しによる荷重の反転で引張力を受けた時に初亀裂が発生 することが肉眼で観察され，続く圧縮再載荷で曲げ弓張 側である凸側に新たに亀裂が発生する過程が認められ た。

2）正たわみモードでは，局部座屈が全体座屈とほぼ同 
時に生じ，幅厚比の大きい場合には材のねじれを伴って 現れた。ねじれは細長比が大きい場合に顕著に現れた。 龟裂は局部座属発生部において生じた。破断時のサイク ル数は, 幅厚比が小さいほよ゙少なく、また細長比が大き いほど少なくなった。

3）荷重-軸方向変位曲線で囲まれる面積から算定され る累積履歴吸収エネルギーは, 累積量が特定の值を超え た時に亀裂が発生するという訳ではなく，また最終的な 破断にかかわるエネルギー量を特定の值で表すことはで きない。しかし同一形状の試験体を用いた同一の載荷履 歴とたわみモードによる載荷では，エネルギー吸収能力 は同程度に発現されている。繰り返しに伴う履歴吸収工 ネルギーの累積過程は, 極低サイクル疲労破壊と単純な 関係にはないが，載荷履歴・たわみモ一ド・幅厚比・細 長比の影響を著しく反映するといえる。

4）本実験で行った $G$ 型， $S$ 型のような振幅変動を伴う 載荷経路の変化に対しては，エネルギ一吸収過程への影 響はあまり顕著ではないが，初めに大きい振幅の載荷を 行った方が破断繰り返しサイクル数が少なく，やや損傷 が大きい傾向を示す。

5）亀裂が発生した部位における局所の残留ひずみは, 亀裂による間隙を除いて算定した正味のひずみによる と, 曲げ圧縮側・曲げ引張側共, 絶対値で $25 \sim 40 \%$ の 範囲にあり，載荷履歴・たわみモード・幅厚比・細長比 にかかわらず，ほぼ同一であった。

\section{謝 辞}

実験の試験体準備に使用したVickers 硬度計の利用に あたり, 京都大学工学部工業化学教室の田中勝久助手な らびに同化学研究所の幸塚広光助手のご協力を得た。こ こに記し，深甚の謝意を表する。

\section{参考文献}

1）佐藤正信，城野政弘：材料の強度・破壊とその評価法, 材料, Vol.41，No. 462，pp. 389 395, 1992.3.

2）岩井 哲, 野中泰二郎：繰返し載荷を受ける構造部材の 塑性疲労一研究の現状分析と展望一, 京都大学防災研究 所年報, 第 31 号 B-1, pp. 89 104, 1988. 4.

3) Nonaka, T., and S. Iwai : Failure of Bar Structures under Repeated Loading, Chap. 12 in "Structural Failure”, (Wierzbicki, T., and Jones, N., Ed.) John Wiley \& Sons Inc., New York, pp. 389 433, 1989.

4) Tanabashi, R., Y. Yokoo, M. Wakabayashi, T. Nakamura, H. Kunieda, H. Matsunaga and T. Kubota : Load-Deflection Behaviors and Plastic Fatigue of WideFlange Beams Subjected to Alternating Plastic Bending Part I Experimental Investigation, Trans. AIJ, No. 175 , pp. 17 29, 1970.9 .

5) Tanabashi, R., Y. Yokoo, T. Nakamura, T. Kubota and A. Yamamoto: Load-Deflection Behaviors and Plastic Fatigue of Wide-Flange Beams Subjected to Alternating Plastic Bending Part II Hysteretic and
Skeleton Stress-Strain Relations and Plastic Fatigue of Flanges, Trans. AIJ, No. 176, pp. 25 36, 1970.10.

6) Tanabashi, R, , Y. Yokoo and T. Nakamura: LoadDeflection Behaviors and Plastic Fatigue of WideFlange Beams Subjected to Alternating Plastic Bending Part III Steady-State Theory, Trans. AIJ, No. 177, pp. 35 46, 1970. 11.

7）後藤尚男, 車田弘行, 小池 武, 泉並隆二, 脇田和試, 杉原 䇸：くり返し曲げ荷重下における構造用鍓材の破 壊過程に関する一考察, 京都大学防災研究所年報, 第 17 号 B, pp. 157 169, 1974. 4.

8) 後藤尚男, 亀田弘行, 小池 武, 青山 功, 脇田和試： 構造用鋼材の塑性疲学破壊に関する確率統計的考察, 京 都大学防災研究所年報, 第 18 号 B, pp. 377 393, 1975.4.

9) Krawinkler, H., and M. Zohrei : Cumulative Damage in Steel Structures Subjected to Earthquake Ground Motions, Computers and Structures, Vol.16, No.1-4, pp. $531 \sim 541,1983$.

10）宇田川邦明，高梨晃一，田中 尚：繰り返し載荷を受け るH形鋼はりの復元力特性（その1・定変位振幅繰り返 し載荷時の塑性ヒンジ回転能力)，日本建築学会論文報告 集, 第 264 号, pp. 51 59, 1978. 2.

11）宇田川邦明, 高梨晃一, 田中 尚：繰り返し載荷を受け るH形鋼はりの復元力特性（その 2 ・ランダム変位履歴 における耐力の低下)，日本建築学会論文報告集， 第 265 号, pp. 45 52, 1978. 3.

12）鈴木敏郎, 王松健一郎：低層鉄骨造骨組柱材のエネルギー 吸収能力に関する実験的研究（その1・単調載荷および 定変位振幅載荷を受ける $\mathrm{H}$ 形鋼柱材のエネルギー吸収能 力), 日本建築学会論文報告集, 第 279 号, pp. 65 75, 1979. 5 .

13）鈴木敏郎, 王松健一郎：低層鉄骨造骨組柱材のエネルギー 吸収能力に関する実験的研究 (その $2 \cdot$ 変動変位振幅を 受けるH形鋼柱材のエネルギー吸収能力), 日本建築学会 論文報告集, 第 280 号, pp. 19 25，1979.6.

14) Yamada, M. : Low Cycle Fatigue Fracture Limits of Various Kinds of Structural Members Subjected to Alternately Repeated Plastic Bending under Axial Compression as an Evaluation Basis or Design Criteria for Aseismic Capacity, Proc. 4th World Conf. Earthq. Eng., Santiago, Vol. I, B2, pp. 137 151, 1969.

15）加藤 勉，秋山 宏：鋼構造部材の耐力（その 4), 日本 建築学会論文報告集，第 151 号，pp. 15～20，1968.9.

16) Kato, B., and H. Akiyama: Inelastic Bar Subjected to Thrust and Cyclic Bending, Jour. Strct. Div., Proc. ASCE, Vol.95, No.ST1, pp.33 56, 1969.1.

17) Neale, K., and J. Schroeder : Instability under Cycles of Plastic Deformation, Instability of Continuous Sys. tems (IUTAM Symposium Herrenalb [Germany], Edited by Leipholz, H.), Springer-Verlag, Berlin, pp. 329 333, 1969. 9.

18) Miner, M. A. : Cumulative Damage in Fatigue, Jour. Applied Mechanics, ASME, Vol.12, pp. A 159 A 164, 1945.

19) Suidan, M.T., and R. A. Eubanks: Cumulative Fatigue Damage in Seismic Structures, Jour. Strct. Div., 
Proc. ASCE, Vol. 99, No. ST5, pp. 923 943, 1973.5.

20) Kaneta, K., I. Kohzu and H. Nishizawa : Cumulative Damage of Welded Beam-to-Column Connections in Steel Structures Subjected to Destructive Earthquakes, Proc. 8th World Conf. Earthq. Eng., San Francisco, Vol. 6, pp. 185 192, 1984.7.

21）西垣太郎，水畑耕治：鉄筋コンクリート柱の低サイクル 疲労に関する奉験的研究，日本建築学会論文報告集，第 328 号, pp. $60 \sim 70,1983.6$.

22）西垣太郎，水畑耕治：鉄筋コンクリート構造物の動的酎 震性評価に関する研究，日本建築学会論文報告集，第 332 号, pp. 19 29, 1983. 10.

23) Park, Y.-J., and A.H.-S. Ang : Mechanistic Seismic Damage Model for Reinforced Concrete, Jour. Struct. Eng., Proc. ASCE, Vol.111, No.ST4, pp.722 739, 1985. 4.

24) Park, Y.-J., A. H. -S. Ang and Y. K. Wen : Seismic Damage Analysis of Reinforced Concrete Buildings, Jour. Struct. Eng., Proc. ASCE, Vol.111, No.ST4, pp. 740 757, 1985. 4 .

25）岩井 哲, Ulrich Bourgund, 野中泰二郎：繰返し載荷を 受ける構造部材の塑性疲労一鋼板要素の破壊実験一, 京 都大学防災研究所年報, 第 32 号 B-1, pp. 133 147,
1989. 4.

26) Iwai, S., T. Nonaka, U. Bourgund and H. Kameda : Structural Failure Due to Very Low Cycle Fatigue of Steel Members and Elements under Earthquake Loading, 第 8 回日本地震工学シンポジウム論文集, pp. 1377 1382, 1990. 12 .

27）桑村 仁, 前田孝一：低 YR 高張力鋼の機械的性質に及 ぼす昰速度の影響，構造工学論文集，Vol. 36 B , pp. 385 -397, 1990. 3 .

28）例えば, 若林 賽 (編著)：鉄骨棈造学詳論, 丸善, p. 152, 1985.

29）高橋 治, 平野道勝, 穂積唀雄, 金子 聡：繰り返し荷 重を受ける筋違の崩壊性状に関する実験的研究〈その 1 : 山形鋼筋違), 日本建築学会大会学術講演梗概集, C構 造 II, pp. 1431 1432, 1991. 9.

30）岩井 哲, 朴 錬洙, 野中泰二郎, 龟田弘行：山形銅部 材の極低サイクル疲労破壊実験, 京都大学防災研究所年 報, 第 34 号 B-1, pp. 71 85, 1991. 4.

31）岩井哲, 朴 鍊洙, 野中泰二郎, 龟田弘行 : 山形鋼部 材の極低サイクル疲労破壊実験（その2）, 京都大学防災 研究所年報，第 35 号 B-2, pp. 509 524, 1992.4.

（1992 年 7 月 10 日原稿受理， 1992 年 12 月 3 日採用決定） 